\title{
Development of a Clothing Sizing System for Benghazian School Girls Students Based on Anthropometric Measurements
}

\begin{abstract}
Salima A.
Bilhassan

Benghazi

University,

Benghazi,

Libya
\end{abstract}

\author{
Hadeer Berras \\ Ali \\ Benghazi \\ University, \\ Benghazi, \\ Libya
}

\author{
Hamida \\ Boushagour \\ Benghazi \\ University, \\ Benghazi, \\ Libya
}

\author{
Hend Mohmed \\ Benghazi \\ University, \\ Benghazi, \\ Libya
}

\author{
Naema \\ Alobaidy \\ Benghazi \\ University, \\ Benghazi, \\ Libya
}

\begin{abstract}
Clothing plays an important role in the performance and movement of the human body in different age groups so the development of clothing sizing system is the best way to provide the best suitable size in clothing design. The current project is the fourth step towards the overall objective to develop a clothing sizing system for Libyan children based on anthropometric body measurements of Libyan school children. The aim of the current project is to examine anthropometric measurements for female students in grades seven, eight and nine in the basic education stage, to collect body measurements of school children in Benghazi and analyze those using simple statistical methods to understand the body ranges and variations present for students in the three grades to develop sizing system of these grades. Twenty body dimensions were measured for each student to develop clothing sizing system. The measurements were gathered from a total of 180 students (children of age 12 to 14 years old, females) from four schools in Benghazi. The anthropometric data were analyzed using Minitab program. ANOVA tests were used to identify differences between age groups. The results showed that there are differences between most of the body measurements except the head circumference, shoulder to shoulder length, shoulder to waist length, front body width, back body width, knee height. These differences were taken into account when developing sizing system. Pearson correlation coefficients analysis was carried out to determine the interrelationships between the various body measurements. From these findings it may be concluded that the weight, chest circumference, is very strongly correlated with some other dimensions. The mean values and the standard deviation were used for creating size steps for the size chart. Three kinds of sizes were identified: L (large), M (medium) and S (small).
\end{abstract}

Keywords: Anthropometric data; sizing system; clothing; schoolchildren; Children anthropometry.

\section{INTRODUCTION}

Clothing fit is the main objective in the garment development process to ensure user comfort and appearance. It is a complex aspect influenced on one side by the anthropometry and body dimensions of the customer and, in the other, by the appearance and social trends [12].

Anthropometry is the science that measures the range of body size in a population. In order to develop standards and solve variations in body size, many scholars agree on the needs to measure human body dimensions for different reasons such as geographical location, nutrition, ethnic group, etc. Due to this, different countries have their own standard body dimension or size standards. Anthropometric data of country are vital database for clothing design and other design applications. It commonly develops in many other countries of the world [1,2, $4,5,6,7,10,13,14,15,16,17$ and 18].

Based on that, clothing manufacturers produce different garments for intended people from the standard body measurements. This study develops size measurements of uniform school clothing for Benghazi city girls based on data collected from schools in the city.

This study is motivated by the need to examine anthropometric measurements among school children in Libya; to develop garment sizing systems for Libyan school students. The aim of the current study is to examine anthropometric measurements for female students in grades seven, eight and nine in the basic education stage, to collect body measurements of school children and analyze those using simple statistical methods to understand the body ranges and variations present for students to develop size chart of these grades

\section{Methodology}

This section explains the material and method used in this research.

\subsection{Participants}

A sample comprising of 180 female students was identified for participation in this study. The sample was randomly selected from four schools (three public schools and one private school) 
in Benghazi during 2017/2018. An equal number of children (60 students) were measured per groups (12 to 14 years). Measurements were taken with the permission of officials and school principals. Table 1 contains a summary of the number of schools and students surveyed.

\subsection{The Body Measurements}

Based on the objective of this project, only twenty anthropometric dimensions are selected and used to establish the clothing sizing systems for students. These dimensions are selected based on previous studies [1, 5, and 7]. Table 2 and Fig. 1 to Fig. 3 show the body dimensions. These measurements are used to make different types of clothing such as school uniforms. The measurements were taken from the left or right sides of the body for participants are left-handed or righthanded respectively. However, most of the measurements were taken from the right side of the body. While their anthropometric measurements were taken, respondents wore light cloths to get accurate readings. Respondents were also told not to wear shoes when their height and weight measurements were taken. During anthropometric data measurements, two kinds of equipment were used measuring tape. Readings were also taken two times and the average of the readings was recorded as the actual anthropometric measurements of the respondents.

Table 1. Frequency table of children selected for measuring in the study

\begin{tabular}{|c|c|c|c|c|c|}
\hline \multirow{3}{*}{ School Name } & \multirow{3}{*}{ Neighbourhood } & \multirow{2}{*}{\multicolumn{3}{|c|}{$\begin{array}{c}\begin{array}{c}\text { Total number } \\
\text { measured }\end{array} \\
\text { Grade }\end{array}$}} & \multirow{3}{*}{ Total } \\
\hline & & & & & \\
\hline & & 12 & 13 & 14 & \\
\hline $\begin{array}{c}\text { FTAT } \\
\text { ALTHORH }\end{array}$ & ALSALMANY & & 45 & 45 & 90 \\
\hline ALSHOALH & $\begin{array}{c}\text { ARTH } \\
\text { ALHIRASA }\end{array}$ & 60 & - & - & 60 \\
\hline SHBEALIA & ALFOYHAT & - & 8 & 4 & 12 \\
\hline $\begin{array}{l}\text { ALSHRWQ } \\
\text { ALAFRIQI }\end{array}$ & ALSALMANY & - & 7 & 11 & 18 \\
\hline \multicolumn{2}{|c|}{ Total } & 60 & 60 & 60 & 180 \\
\hline
\end{tabular}

Table 2. The Anthropometric Dimension

\begin{tabular}{|c|c|c|c|}
\hline No & Body Dimension & No & Body Dimension \\
\hline 1 & Weight & 11 & $\begin{array}{c}\text { Shoulder to waist } \\
\text { length }\end{array}$ \\
\hline 2 & Height & 12 & Front body length \\
\hline 3 & Head circumference & 13 & Back body length \\
\hline 4 & Neck circumference & 14 & Waist to hips length \\
\hline 5 & Waist circumference & 15 & Shoulder length \\
\hline 6 & Chest circumference & 16 & Front body width \\
\hline 7 & Hip circumference & 17 & Back body width \\
\hline 8 & Arm circumference & 18 & Calf circumference \\
\hline 9 & $\begin{array}{c}\text { Shoulder to shoulder } \\
\text { length }\end{array}$ & 19 & Knee circumference \\
\hline 10 & Shoulder to wrist length & 20 & Outside leg length \\
\hline
\end{tabular}

\subsection{Anthropometric Data Analysis}

After conducting the anthropometric survey, the data obtained from this study was analyzed using Minitab 17.1 Statistical Package Program for Windows. Descriptive statistics, such as mean, min., max. and standard deviation were used to describe and summarize the data collected. The normality test was used to determine if a data collected is well- modeled by a normal distribution. As expected, data for all measurements followed a normal distribution. Subsequently, ANOVA analysis was carried out to identify differences between age groups. ANOVA was carried out for all dimensions. Moreover, Pearson 
correlation coefficients analysis was carried out to determine the interrelationships between the various body measurements. The results from these tests were used to develop the clothing sizing system [1].

\section{Results And Discussion}

\subsection{Descriptive Analysis}

As expected that all measurements follow a normal distribution. The mean and standard deviation for all measurements are shown in Table 2. The standard deviation (SD) for almost all dimensions is quite large, showing great variation in the measurements.

Table 2. 2 The mean and standard deviation by age in $\mathrm{cm}$

\begin{tabular}{|c|c|c|c|}
\hline \multirow{2}{*}{$\begin{array}{c}\text { Body } \\
\text { dimensions }\end{array}$} & \multicolumn{3}{|c|}{ Grade } \\
\hline & 7 & 8 & 9 \\
\hline 1 & $\begin{array}{c}43.69 \\
(15.63)\end{array}$ & $\begin{array}{c}53.14 \\
(12.37)\end{array}$ & $\begin{array}{l}53.77 \\
(4.95)\end{array}$ \\
\hline 2 & $\begin{array}{c}147.27 \\
(8.53)\end{array}$ & $\begin{array}{c}154.48 \\
(6.28)\end{array}$ & $\begin{array}{c}157.18 \\
(2.86)\end{array}$ \\
\hline 3 & $\begin{array}{l}54.51 \\
(1.74)\end{array}$ & $\begin{array}{l}54.88 \\
(1.98)\end{array}$ & $\begin{array}{l}54.82 \\
(0.11)\end{array}$ \\
\hline 4 & $\begin{array}{l}28.19 \\
(2.53)\end{array}$ & $\begin{array}{l}31.49 \\
(2.54)\end{array}$ & $\begin{array}{c}31.7 \\
(4.24)\end{array}$ \\
\hline 5 & $\begin{array}{c}65.74 \\
(13.56) \\
\end{array}$ & $\begin{array}{l}71.99 \\
(9.98)\end{array}$ & $\begin{array}{l}70.46 \\
(8.34) \\
\end{array}$ \\
\hline 6 & $\begin{array}{c}70.03 \\
(11.86) \\
\end{array}$ & $\begin{array}{l}81.58 \\
(9.75)\end{array}$ & $\begin{array}{l}81.46 \\
(2.16) \\
\end{array}$ \\
\hline 7 & $\begin{array}{c}77.34 \\
(13.06) \\
\end{array}$ & $\begin{array}{c}88.82 \\
(13.05) \\
\end{array}$ & $\begin{array}{l}90.31 \\
(2.58)\end{array}$ \\
\hline 8 & $\begin{array}{l}23.19 \\
(4.05)\end{array}$ & $\begin{array}{l}26.72 \\
(3.57)\end{array}$ & $\begin{array}{c}26.13 \\
(1.59)\end{array}$ \\
\hline 9 & $\begin{array}{l}37.35 \\
(3.26)\end{array}$ & $\begin{array}{l}38.63 \\
(3.41)\end{array}$ & $\begin{array}{l}37.64 \\
(0.81)\end{array}$ \\
\hline 10 & $\begin{array}{l}55.30 \\
(4.87) \\
\end{array}$ & $\begin{array}{l}54.03 \\
(4.52) \\
\end{array}$ & $\begin{array}{l}56.62 \\
(0.64) \\
\end{array}$ \\
\hline 11 & $\begin{array}{l}34.84 \\
(3.40) \\
\end{array}$ & $\begin{array}{l}34.99 \\
(3.60) \\
\end{array}$ & $\begin{array}{l}35.89 \\
(1.91)\end{array}$ \\
\hline 12 & $\begin{array}{l}32.32 \\
(3.14)\end{array}$ & $\begin{array}{l}34.46 \\
(3.16)\end{array}$ & $\begin{array}{l}35.82 \\
(1.66)\end{array}$ \\
\hline 13 & $\begin{array}{l}35.32 \\
(3.02) \\
\end{array}$ & $\begin{array}{l}37.40 \\
(4.37) \\
\end{array}$ & $\begin{array}{r}37.89 \\
(2.01) \\
\end{array}$ \\
\hline 14 & $\begin{array}{l}25.84 \\
(3.40)\end{array}$ & $\begin{array}{l}19.93 \\
(5.12)\end{array}$ & $\begin{array}{l}24.32 \\
(1.45)\end{array}$ \\
\hline 15 & $\begin{array}{l}11.95 \\
(1.68) \\
\end{array}$ & $\begin{array}{r}14.13 \\
(1.84) \\
\end{array}$ & $\begin{array}{l}13.81 \\
(1.45)\end{array}$ \\
\hline 16 & $\begin{array}{l}35.57 \\
(4.82)\end{array}$ & $\begin{array}{l}36.88 \\
(4.52)\end{array}$ & $\begin{array}{l}36.29 \\
(4.95)\end{array}$ \\
\hline 17 & $\begin{array}{c}36.98 \\
(22.40)\end{array}$ & $\begin{array}{l}38.38 \\
(3.62)\end{array}$ & $\begin{array}{l}36.64 \\
(4.95)\end{array}$ \\
\hline 18 & $\begin{array}{l}30.23 \\
(4.87)\end{array}$ & $\begin{array}{l}33.67 \\
(3.23)\end{array}$ & $\begin{array}{l}33.66 \\
(3.57)\end{array}$ \\
\hline 19 & $\begin{array}{l}45.11 \\
(3.58)\end{array}$ & $\begin{array}{c}45.65 \\
(24.36)\end{array}$ & $\begin{array}{l}45.05 \\
(1.41)\end{array}$ \\
\hline 20 & $\begin{array}{l}70.55 \\
(6.76)\end{array}$ & $\begin{array}{l}74.40 \\
(5.84)\end{array}$ & $\begin{array}{l}75.20 \\
(3.30)\end{array}$ \\
\hline
\end{tabular}

\subsection{Differences of Anthropometric}

\section{Measurements by gender}

The results of ANOVA test show that almost all of the anthropometric measurements have significant differences (P- value < 0.05) between the ages of respondents. These differences would be considered to design clothing sizing systems for different age groups. There are no differences in the Head circumference, Shoulder to shoulder length, Shoulder to waist length, Front body width, Back body width and Knee height between ages groups as shown in Table 3. Therefore, these differences mean that age is one element that influences the development of the human body, and will eventually affect the sizes of clothing [3].

Table 3. Differences of anthropometric measurements by age using ANOVA test

\begin{tabular}{|c|c|c|c|}
\hline MEASUREMET & F & P-Value & Sig. \\
\hline Head circumference & $\mathbf{0 . 5 2}$ & $\mathbf{0 . 5 9 3}$ & Not Sig. \\
\hline Shoulder to shoulder length & 2.66 & $\mathbf{0 . 0 7 3}$ & Not Sig. \\
\hline Shoulder to waist length & $\mathbf{0 . 8 9}$ & $\mathbf{0 . 4 1 4}$ & Not Sig. \\
\hline Front body width & 1.13 & $\mathbf{0 . 3 2 5}$ & Not Sig. \\
\hline Back body width & $\mathbf{0 . 2 9}$ & $\mathbf{0 . 7 4 8}$ & Not Sig. \\
\hline Knee height & $\mathbf{0 . 0 3}$ & $\mathbf{0 . 9 6 9}$ & Not Sig \\
\hline
\end{tabular}

\subsection{Correlation Analysis}

A key measurement should also be a body measurement with strong relationships with most other body dimensions. Consequently based on this selection, it was possible to develop sizing system. They can be good predictors of the size of other parts of the body. The criteria for key measurements vary and there are various methods to be established in this regard. By using correlation coefficients it could be possible to identify key measurements. Correlation coefficient values indicate the strength of linear relationships between variables and were, as such, implemented in this study.

Pearson correlation coefficients analysis was carried out to determine the interrelationships between the various body measurements. The Pearson correlation coefficient (r) is a measure of the strength of the linear relationship between two random variables. Correlation coefficients range from -1.00 to +1.00 . The value of -1.00 represents a perfect negative correlation (indicating a perfect negative linear relationship between variables) and a value of +1.00 represents a perfect positive correlation (indicating a perfect positive linear relationship between variables). A value of 0.00 reflects no correlation (no linear relationship) between the respective variables.

The following arbitrary scale for correlations was implemented to indicate the strength of the relationship between measurements (Gupta and Gangadhar, 2004):

- If correlation coefficient is, 0.5 then no relationship;

- If correlation coefficient is between 0.5 and 0.75 then there is a mild relationship;

- If correlation coefficient is 0.76 it indicates a strong relationship [13].

Table 4 illustrates relationships between measurements and shows the correlation coefficients between each measurement and the other. It is noted that the weight measurement appears to have strong relationships with waist circumference, chest circumference, hip circumference, arm circumference and calf circumference width. Head circumference has strong relationship with waist circumference. Neck circumference has 
strong relationship with chest circumference. Waist circumferences have strong relationships with chest circumference and arm circumference. Chest circumference has strong relationships with hip circumference, arm circumference and calf circumference. Arm circumference has strong relationship with calf circumference.

From these findings it may be concluded that weight measurement is the most critical measurement. Weight and chest circumference are key measurements to body garments. In general, it can be inferred that theses dimensions are the important landmarks on the body and hence should be related closely to the garment measurements.

Table 4. Correlation coefficients

\begin{tabular}{|c|c|c|c|c|c|}
\hline $\begin{array}{c}\text { Measurme } \\
\text { nts }\end{array}$ & $\mathbf{5}$ & $\mathbf{6}$ & $\mathbf{7}$ & $\mathbf{8}$ & $\mathbf{1 8}$ \\
\hline 1 & $\begin{array}{c}0.836 \\
* *\end{array}$ & $\begin{array}{c}0.899 \\
* *\end{array}$ & $\begin{array}{c}0.798 \\
* *\end{array}$ & $\begin{array}{c}0.845 \\
* *\end{array}$ & $\begin{array}{c}0.833 \\
* *\end{array}$ \\
\hline 4 & $\begin{array}{c}0.659 \\
*\end{array}$ & $\begin{array}{c}0.775 \\
* *\end{array}$ & $0.66 *$ & $\begin{array}{c}0.694 \\
*\end{array}$ & $0.7 *$ \\
\hline 5 & 1 & $\begin{array}{c}0.842 \\
* *\end{array}$ & $\begin{array}{c}0.737 \\
*\end{array}$ & $\begin{array}{c}0.788 \\
* *\end{array}$ & $\begin{array}{c}0.755 \\
*\end{array}$ \\
\hline 6 & & 1 & $\begin{array}{c}0.804 \\
* *\end{array}$ & $\begin{array}{c}0.809 \\
* *\end{array}$ & $\begin{array}{c}0.821 \\
* *\end{array}$ \\
\hline 8 & & & & 1 & $\begin{array}{c}0.781 \\
* *\end{array}$ \\
\hline
\end{tabular}

\subsection{Development of Size Chart}

The development of the size chart was carried out using values obtained from the statistical information based on the ANOVA test of body dimensions. The mean values and the standard deviations were used for creating size steps for the size chart. Therefore, different sizes of clothing for girls aged 12, 13 and 14 years must be developed due to the differences in some measurements between age groups. Three sizes were developed: S (small), M (medium) and L (large). These sizes were developed because of there were multiple body shape in each group of 12, 13 and 14 years old.

Three-size steps approach was used to develop the size chart for all body dimensions. To obtain three steps for three categories of body sizes, two standard deviations (2SD) value is added to the mean to obtain one value that is higher than the mean. Two standard deviations (-2SD) values are subtracted from the mean sequentially to obtain one value that is less than the mean for all body dimensions except key body dimensions. There is a difference between ages in height measurement and most of the measurements based on ANOVA analysis. One of the values can be calculated if there is no difference between each parameter. However, three values can be calculated if there is difference between each parameter according to ANOVA.

Table 5 shows the size codes together with the body dimensions. They were calculated into three categories depend on the weight and chest circumference which are very strongly correlated with some of dimensions.

\section{Conclusion}

The following conclusions were derived

1. As expected that all measurements follow a normal distribution.

2. From the results of ANOVA test, there were differences of anthropometric measurements between age groups except the head circumference, shoulder to shoulder, shoulder to waist length, front body width, back body width and knee height.
3. The key dimensions should be those, which have the strongest correlations with most other body dimensions using Pearson correlation coefficients analysis. From these findings it may be concluded that the weight and chest circumference is very strongly correlated with some of dimensions. In general, it can be inferred that theses dimensions are the important landmarks on the body and hence should be related closely to the garment measurements.

The next phase in the ongoing study is to finish gathering anthropometric data and evaluation for the remaining grades in the education stage. After that database for sizing system in the Libya are going to be established.

\section{ACKNOWLEDGMENTS}

This study is a part of a BSc project of Industrial and manufacturing systems engineering Fall 2017/2018, conducted at School of Industrial and Manufacturing Systems Engineering at University of Benghazi. The authors would like to thank all participants for their contributions.

Table 5 Clothing Size Chart of Respondents (CM)

\begin{tabular}{|c|c|c|c|}
\hline Measurements & $\mathbf{S}$ & $\mathbf{M}$ & $\mathbf{L}$ \\
\hline \multicolumn{4}{|l|}{1} \\
\hline 12 & 12.42 & 43.69 & 74.96 \\
\hline 13 & 28.40 & 53.14 & 77.88 \\
\hline 14 & 43.87 & 53.77 & 63.66 \\
\hline \multicolumn{4}{|l|}{2} \\
\hline 12 & 130.22 & 147.27 & 164.32 \\
\hline 13 & 141.92 & 154.48 & 167.04 \\
\hline 14 & 151.45 & 157.18 & 162.91 \\
\hline 3 & 50.55 & 54.73 & 58.91 \\
\hline \multicolumn{4}{|l|}{4} \\
\hline 12 & 23.13 & 28.19 & 33.25 \\
\hline 13 & 26.41 & 31.49 & 36.56 \\
\hline 14 & 23.22 & 31.70 & 40.19 \\
\hline \multicolumn{4}{|l|}{5} \\
\hline 12 & 38.61 & 65.74 & 92.86 \\
\hline 13 & 52.03 & 72.00 & 91.96 \\
\hline 14 & 53.77 & 70.46 & 87.15 \\
\hline \multicolumn{4}{|l|}{6} \\
\hline 12 & 46.30 & 70.03 & 93.76 \\
\hline 13 & 62.08 & 81.58 & 101.08 \\
\hline 14 & 77.15 & 81.46 & 85.78 \\
\hline \multicolumn{4}{|l|}{7} \\
\hline 12 & 51.22 & 77.34 & 103.47 \\
\hline 13 & 62.73 & 88.82 & 114.91 \\
\hline 14 & 85.15 & 90.31 & 95.47 \\
\hline \multicolumn{4}{|l|}{8} \\
\hline 12 & 15.08 & 23.19 & 31.29 \\
\hline 13 & 19.57 & 26.72 & 33.86 \\
\hline 14 & 22.95 & 26.13 & 29.32 \\
\hline 9 & 31.43 & 37.87 & 44.32 \\
\hline \multicolumn{4}{|l|}{10} \\
\hline 12 & 45.57 & 55.30 & 65.03 \\
\hline 13 & 45.00 & 54.03 & 63.07 \\
\hline 14 & 55.35 & 56.62 & 57.89 \\
\hline 11 & 25.94 & 35.24 & 44.54 \\
\hline \multicolumn{4}{|l|}{12} \\
\hline 12 & 26.04 & 32.32 & 38.61 \\
\hline 13 & 28.14 & 34.46 & 40.78 \\
\hline 14 & 32.50 & 35.82 & 39.14 \\
\hline \multicolumn{4}{|l|}{13} \\
\hline 12 & 29.27 & 35.32 & 41.36 \\
\hline 13 & 28.66 & 37.40 & 46.14 \\
\hline 14 & 33.86 & 37.89 & 41.99 \\
\hline
\end{tabular}




\begin{tabular}{|cc|c|c|c|}
\hline \multicolumn{2}{|c|}{ Measurements } & S & M & L \\
\hline $\mathbf{1 4}$ & & & & \\
\hline & 12 & 19.04 & 25.84 & 32.64 \\
\hline & 13 & 9.69 & 19.93 & 30.17 \\
\hline & 14 & 21.42 & 24.32 & 27.22 \\
\hline $\mathbf{1 5}$ & & & & \\
\hline & 12 & 8.58 & 11.95 & 15.32 \\
\hline & 13 & 10.45 & 14.13 & 17.81 \\
\hline & 14 & 10.92 & 13.81 & 16.71 \\
\hline $\mathbf{1 6}$ & & 26.67 & 36.25 & 45.82 \\
\hline $\mathbf{1 7}$ & & 10.84 & 37.33 & 63.83 \\
\hline $\mathbf{1 8}$ & & & & \\
\hline & 12 & 20.49 & 30.23 & 39.97 \\
\hline & 13 & 27.20 & 33.67 & 40.14 \\
\hline & 14 & 26.52 & 33.66 & 40.80 \\
\hline $\mathbf{1 9}$ & & 16.62 & 45.27 & 73.92 \\
\hline $\mathbf{2 0}$ & & & & \\
\hline & 12 & 57.04 & 70.55 & 84.06 \\
\hline & 13 & 62.72 & 74.40 & 86.07 \\
\hline & 14 & 68.62 & 75.20 & 81.78 \\
\hline
\end{tabular}

\section{REFERENCES}

[1] Adu-Boakye, S., Power, J., Wallace, T., Chen, Z. 2012. Development of a Sizing System for Ghanaian Women for the Production of Ready-To-Wear Clothing. In: The 88th Textile Institute World Conference 2012, 15th-17th May 2012, Selangor, Malaysia.

[2] Alarody, 1., Kared, M., Abdelmalek, S. Fall 2015/2016. An anthropometric study to develop clothing charts for Benghazi school-children; BSc Project, Industrial and Manufacturing Systems Engineering Department; University of Benghazi.

[3] Albarki, F., Bu-Hager, A., Basheer, M., Ali, M., Spring 2017. An anthropometric study to develop clothing charts for seventh, eighth and ninth grades of Benghazi, schoolchildren, BSc Project, Industrial and Manufacturing Systems Engineering Department; University of Benghazi.

[4] Aminian, O., Negin, R., and Fairuz, I., (2012) Mismatch between anthropometric body dimensions and classroom furniture in Malaysian universities, Canadian engineering education association (CEEA12) Conference.

[5] Ariadurai, A. S., Nilusha, T. P. G. and Dissanayake, M. R. 2009. An anthropometric study on Sri Lankan school children for developing clothing sizes, Journal of Social Science, 19, 51- 56.

[6] Bari, S., Salleh, N., Sulaiman, N., and Othman, M. 2015. Development of Clothing Size for Pre School Children Based on Anthropometric Measurements, Australian Journal of Sustainable Business and Society', 1(2), 22-32.

[7] Beazley, A. 1999. Size and fit: The development of size charts for clothing-Part 3, Journal of Fashion Marketing and Management, 3, 66-84.

[8] Bilhassan, S., ELMABROK, A., ELMEHASHHSH, K., Ali, H., Kaddom, A., Elhouni, H. 2018. Development of a Clothing Sizing System for Benghazian Children Based on Anthropometric Measurements, The International Journal of Engineering And Information Technology (IJEIT), 4 (2), 136-140.

[9] Bilhassan*, S., Albarki, F., Bu-Hager, A., Basheer, M., Ali, M. 2018. An anthropometric study to develop clothing charts for seventh, eighth and ninth grades of Benghazi, schoolchildren, Libyan Journal of Science \& Technology, 7(2), 61-64.
[10] Chung, M.J., Lin, H.F. and Wang, M.J.J. 2007. The development of sizing systems for Taiwanese elementary and high school stu-dents, International Journal of Industrial Ergonomics, 37, 707-716.

[11] Elmabrok, A., Elmehashhsh, K., Ali, H., Kaddom, A., Elhouni, H. Fall 2016/2017. Development of a clothing sizing system for Benghazi children based on anthropometric measurements; B.Sc. Project, Industrial and Manufacturing Systems Engineering De-partment; University of Benghazi.

[12] Fan. J., Yu, W. and Hunter, L., (2004). Clothing appearance and fit: Science and technology. Woodhead Publishing Limited.

[13] Gupta, D., Gangadhar, B., R. 2004. A statistical model for develop-ing body size charts for garments', International Journal of Clothing Science and Technology, 16(5), 258469 .

[14] Gupta, D. and Zakaria, N. 2014. Anthropometry, apparel sizing and design, Woodhead Publishing Limited, UK, 1st Edition.

[15] Kang, Y., Choi, H., Do, W. H. 2001. A Study of the Apparel Sizing of Children's Wear - An Analysis of the Size Increments Utilized in Children's Wear Based on an Anthropometric Survey', Journal of Korean Home Economics Association English Edition, 2(1), 95-110.

[16] Lee, Y. 2013. Anthropometric Data Analysis for Body Shape Mod-eling in Korean, Korean Journal Physics Anthropology, 26(2), $61-68$.

[17] Muslim, E., Moch, B., Fileinti , N., Puspasari, M., Siberian, T., laksana, D. 2014. The Development of Standard Size for Clothes of Indo-nesian Boys Basedon Anthropometric Data as A Reference to Formulate RSNI 055:2013, International Journal of Ergonomics, 4(2), 1-9.

[18] Zakaria, N. 2011. Sizing System for Functional ClothingUniforms for Schoolchildren', Indian Journal of Fiber and Textile Research, 36, 348-357. 